\title{
A new deep-sea suctorian-nematode epibiosis (Loricophrya-Tricoma) from the Blanes submarine canyon (NW Mediterranean)
}

\author{
Gregorio Fernandez-Leborans ${ }^{1}$, Sara Román ${ }^{2}$ and Daniel Martin ${ }^{2}$
}

1. Departamento de Zoología, Facultad de Biología, Universidad Complutense de Madrid, C/ José Antonio Novais, 12, 28040, Madrid, Spain

2. Department d'Ecologia Marina, Centre d'Estudis Avançats de Blanes, CEAB-CSIC, C/ Accés a la cala St Francesc, 14, 17300, Blanes (Girona), Catalunya (Spain)

\begin{abstract}
During a pluridisciplinar study carried out within the frame of the Spanish research project DOS MARES, multicore samples were collected along the Blanes submarine canyon and its adjacent open slope to study the structure and dynamics of the meiofaunal organisms, mainly nematodes. Among the 5808 nematode individuals identified, only 190 of the belonged to the genus Tricoma (Desmoscolecidae), and only two harboured epibiont suctorian ciliates. The three specimens were located near the tail of the basibionts. A careful examination of the ciliates revealed that they were suctorians, which are here described as a new species of Loricophrya, namely L. mediterranea sp. nov. The new species is characterized by having a conical, slightly elongated lorica, narrowing towards posterior end; an anterior end inward curved, surrounding the lorica opening; a body placed near the lorica opening, occupying $1 / 3$ of the lorica length, 4-8 capitate tentacles, and a peripheral, oval to sausage-shaped macronucleus. Our findings represent the first known report of an association with a deep-sea species of Tricoma, and the first record in the Mediterranean Sea, for a species of Loricophrya. The significance of the relationships between suctorian ciliates and their host in extreme environments such as deep-sea submarine canyons is discussed.
\end{abstract}

KEYWORDS. Epibiosis, nematode, Tricoma, suctorian ciliate, Loricophrya mediterranea sp. nov., Blanes canyon, Deep-sea, NW Mediterranean Sea

\section{INTRODUCTION}

Epibiosis is a relationship involving two organisms, the basibiont and the epibiont, in which the former provides surface for settlement of a sessile phase in the life cycle of the latter (Wahl, 1989). These kinds of associations are very common in marine areas where, quite often, the bottom characteristics are not suitable for the colonization by the epibiotic organisms. However, attachment on a more or less hard substrate is not the only reason (often neither the main) explaining the success of these relationships. They have a highly relevant ecological role and may imply numerous, intimate interactions between the involved organisms, which are usually surface-mediated and, thus, may interfere in the modulation of the basibiont-environment interactions (Wahl, 2008). These interactions are particularly very important in aquatic environments, where the presence of epibionts may negatively affect to (exploitative mediation) or turn to be indifferent for (interference mediation) the basibiont fitness (Wahl, 2008).

The complexity of epibiotic interactions involves different degrees of specialization and specificity, which entails also evolutive processes (Key et al., 1999). Epibionts are generally smaller than basibionts, whose surface shows adequate textures allowing the attachment of the epibionts. Frequently, animal basibionts have mineral or organic covers (cuticles, carapaces, etc.) that can be easily used by the epibionts. 
Protozoans, particularly the ciliates, are among the most common organisms adopting these epibiotic habitus. Habitually, they exhibit sessile and mobile phases in their life cycles, which ensures dispersion and survival of the epibiont, this being obviously reinforced by the role of basibionts (Fernandez-Leborans \& Tato-Porto 2000a, b). In marine environments, ciliates are found living as epibionts of crustacean, echinoderm, molluscan and vertebrate basibionts (Morado \& Small, 1995, Fernandez-Leborans \& Gabilondo, 2005), but they have also been reported from polychaetes (Alvarez-Campos et al. 2014), hydrozoans (Tazioli and di Camilo 2013), mites (Dovgal et al., 2008, 2009b), and kinorhynchs (Dovgal et al, 2008), among others. The nematodes, probably the most abundant meiofaunal marine taxa, have also been reported as basibionts of ciliates, mainly suctorian (e.g., Ansari and Bhadury 2016, Baban et al. 2009, Bhattacharjee 2014, Dovgal et al. 2009a, Fisher 2003, Ingole et al. 2010, Liao and Dovgal, 2015, Muthumbi et al. 1995, Nicholas et al. 1988, Sergeeva and Dovgal 2016).

During a pluridisciplinar study carried out within the frame of the Spanish research project DOS MARES, numerous multicore samples were collected at different depths along the Blanes submarine canyon and its adjacent open slope to study the structure and dynamics of the meiofaunal organisms, mainly nematodes (Roman et al. submitted). Due to their particular geological structure and oceanographic functioning, submarine canyons tend to concentrate more diverse organisms than the adjacent open slopes in the continental shelf. Thus, submarine canyons are considered as deep-sea biodiversity hotspots worldwide, from meio- to megafauna. The Blanes Canyon is not an exception (e.g., Roman et al. submitted, Romano et al., 2013a,b, Tecchio et al. 2013, Sardà et al. 2009). As a result, many studies targeting Blanes Canyon considered describing new species, genera or, even, families, as well as re-describing poorly known ones (Gili et al. 1998, 1999, 2000; Sardá et al. 2009, Sevastou et al. 2012).

Nematodes clearly dominate the meiofaunal assemblages in Blanes Canyon, reaching up to $90 \%$ of the total meiofauna (Roman et al. submitted). However, among the thousands of nematode individuals examined during the DOS MARES project, we have only found two specimens, belonging to of the genus Tricoma, that hosted suctorian ciliate epibionts on their external surface. In this paper, we are describing them as a new species within the genus Loricophrya Matthes, 1956 and we discuss on the significance of the relationships between suctorian ciliates and their host in extreme environments such as deep-sea submarine canyons.

\section{MATERIAL AN METHODS}

Blanes Canyon is the largest canyon of the Catalan margin of the Iberian Peninsula. It measures $184 \mathrm{~km}$ long for a maximum width of $20 \mathrm{~km}$ at its deepest part. The canyon head has a nearly N-S trending course, followed by a meandering course with a flat-floored channel at the base of slope, where it turns to a W-E course before outflowing to the lower Valencia Channel at depths of about $2600 \mathrm{~m}$. The upper canyon is located at around $60 \mathrm{~m}$ depth and at about $4 \mathrm{~km}$ from the coastline where Tordera River reaches the sea (Amblas et al. 2006, Lastras et al. 2011). Within the frame of the DosMares research project, sediment samples were collected in and around the canyon during four cruises in spring and autumn 2012 and 2013, on board of the R/V García del Cid. Among the different stations sampled during these cruises, the basibiont nematode was found at $1200 \mathrm{~m}$ depth inside the axis of the canyon. Sediments were obtained with a 6-tube multicore KC Denmark A/S (inner diameter $9.4 \mathrm{~cm}$; length $60 \mathrm{~cm}$ ), which was carefully sub-sampled on board by means of a small PVC 
core (36 $\mathrm{mm}$ of diameter). The upper $5 \mathrm{~cm}$ of sediment were retained and fixed in buffered $4 \%$ formalin. In laboratory, the fixed sediments were rinsed through a $1000 \mu \mathrm{m}$ mesh sieved, sieved though a $32 \mu \mathrm{m}$ mesh, washed again and centrifuged three times using the colloidal silica polymer LUDOX HS40 (specific gravity 1.18). The supernatant of each washing cycle was again collected on a $32-\mu \mathrm{m}$ sieve, kept in $4 \%$ formalin formaldehyde, and stained with Rose Bengal. Nematodes were sorted and counted under a stereomicroscope (50 x magnification), then transferred gradually to glycerine (De Grisse, 1969), mounted on glass slides and identified under compound microscope (100 x magnification) to genus level, using pictorial keys (Platt and Warwick, 1988) and the taxonomic literature of the Nematode Library at Ghent University. The ciliates were identified using an Image Analysis (Zeiss K 300) system with a Zeiss compound microscope. The measurements of ciliates were made using the computer program ScopePhoto 2.0 for processing the digital images. The scheme of the suctorian ciliate was drawn on the basis of the obtained light microscope images.

The permanent slides of infested organisms are deposited in the Museum fur Naturkunde (MfN, Invalidentstr. 43, Berlin, Germany).

\section{RESULTS}

A total of 5808 nematode individuals have been identified during the development of the DOS MARES research project. One hundred ninety of the belonged to the genus Tricoma, which are small sized nematodes characterized by having a highly ornamented cuticula (Fig. 1). Among them, only two specimens harboured suctorian ciliates, which were located near the tail, on the last third of the body of the nematode. One basibiont was found at $1227 \mathrm{~m}$ depth and harboured two epibionts and the other occurred at $1457 \mathrm{~m}$ depth and harboured a single ciliate. The morphometric and morphological characteristics of the three epibionts agree with those of the genus Loricophrya, and are here described as a new species within this genus.

\section{Taxonomic Account}

Phylum Ciliophora Doflein, 1901

Class Phyllopharyngea De Puytorac et al., 1974

Subclass Suctoria Claparède \& Lachmann, 1858

Order Exogenida Collin, 1912

Family Paracinetidae Jankowski, 1978

Genus Loricophrya Matthes, 1956

Type species: Thecacineta parva Schulz, 1932 
Diagnosis. Freshwater, marine and soil suctoria. Lorica type thecostyle (stylotheca). When clearly differentiated, stem shorter than lorica part of thecostyle. Body ovoid to elongate, rounded in cross-section. Capitate tentacles restricted to a single group on apical surface of zooid. Reproduction by exogemmy, with formation of a single apical protomit. Swarmer oval, with longitudinal ciliary rows and tentacles (Curds, 1987; Dovgal, 2002).

\section{Loricophrya mediterranea $\mathrm{n}$. sp.}

Figures 1-6

Material examined. MfN XXXXXX. Hapantotype slide, 2 specimens, Blanes Canyon, 4130'44"N, 2०50'35"E, $1227 \mathrm{~m}$ depth, 06-04-2013. Collected by Sara Román. MfN

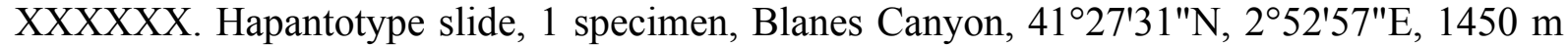
depth, 08-10-2012. Collected by Sara Román.

Description. Suctorian ciliates with a lorica type stylotheca. Lorica conical (32.9-42.4 X 6.8$20.4 \mu \mathrm{m}$ ), slightly elongated, slightly narrowing towards posterior end, with thinest end on surface of basibiont. Anterior, distal end wider, inward curved, surrounding lorica opening . Lorica wall similar in thickness throughout its length. Ciliate body near lorica opening, rounded to somewhat stretched (12.2-19.8 X 11.9-14.6 $\mu \mathrm{m}$ ), occupying 1/3 of lorica length. Body with 4-8 capitate tentacles (4.6-11.7 $\mu \mathrm{m}$ long), not grouped in fascicles, protruding through lorica opening. Macronucleus peripheral, oval to sausage-shaped.

Biometry. Stylotheca length: 32.96-42.45 $\mu \mathrm{m}$; Stylotheca maximum width: 15.56-20.45 $\mu \mathrm{m}$; Stylotheca minimum width: 2.35-6.81 $\mu \mathrm{m}$; Stylotheca opening length: 8.49-14.15 $\mu \mathrm{m}$; Body length: 12.26-19.81 $\mu \mathrm{m}$, thin end on surface of basibiont; Body width: 11.93-14.62 $\mu \mathrm{m}$; Number of tentacles: 4-8; Tentacle length: 4.61-11.79 $\mu \mathrm{m}$; Macronucleus length: 6.67- 8.49 $\mu \mathrm{m}$; Macronucleus width: 3.51- $4.71 \mu \mathrm{m}$.

Remarks. Three Loricophrya species were the most similar to the ciliates found in Blanes Canyon: L. tuba Zelinka, 1913, L. sivertseni (Allgen, 1951) Matthes, 1956 and L. bosporica Seergeva \& Dovgal, 2016 (Table 1). Our suctorians differed from $L$. tuba in having the edge of the lorica curved to the opening (undulated in $L$. tuba), a relative body volume of $1 / 3$ of the lorica (1/4 in $L$. tuba), a peripheral, ovoid to sausage-shaped macronucleus (central, ovoid, transversal in L. tuba) and nematode basibiont (echinoderms in L. tuba).

Loricophrya mediterranea sp. nov. differs from L. sivertseni in having a smaller lorica with an inwards curved opening edge (scalloped in L. sivertseni) and a body partly filling the lorica (completely in L. sivertseni). The also differ in tentacle and macronucleus length. Finally, although the respective basibionts are marine nematodes, it is a deep-sea species of Tricoma for our new species, and the shallow water, tidal pool species Spirinia parasitifera (Bastian, 1865) Gerlach, 1963 for L. sivertseni.

Finally, when compared to L. bosporica, our specimens differ in having the anterior lorica end curved towards the lorica opening (straight, with the lorica wall thicken to the opening in L. bosporica), a longer body, and a peripheral, ovoid to sausage-shaped macronucleus (rounded and central in L. bosporica).

Taking into account these differences, we propose the suctorian ciliates found in the present study as new species, namely Loricophya mediterranea sp. nov. 


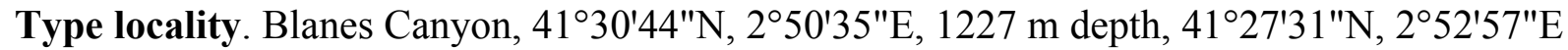
$1450 \mathrm{~m}$ depth.

Type host. Tricoma sp. (Nematoda)

\section{DISCUSSION}

Many epibionts are known to live on nematodes, with a significant number of reports mentioning ciliates, mainly suctorian species, most of them having marine species of the family Desmodoridae as basibionts and belonging to the genus Thecacineta. Thecacineta cothurnioides Collin, 1909 and Trematosoma rotunda (Allgen, 1952) occurred on the Chromaspirina sp. inhabiting shallow waters of the Bay of Bengal (India) (Bhattacharjee, 2014). Thecacineta calix was found as epibiont of two deep-sea species of Desmodora, living in turn as associates of a hexactinellid sponge of the genus Pheronema from the Indian coasts of the Andaman Sea (Indian Ocean). Finally, Thecacineta urceolata Liao \& Dovgal, 2015 was found on Desmodora pontica, which inhabits seagrass beds in the Taiwanese coasts of the Sea of Philippines (Liao \& Dovgal, 2015).

The suctorian genus Loricophrya has also been found as epibiont. For instance, $L$. multitentaculata (Sand, 1895) Matthes, 1956 lives as epibiont on sponges of the genus Leucosolenia; while L. oviformis (Dons 1918) lives on the polychaete Spirorbis sp., L. stresemanni (Allgén, 1951) Matthes, 1956 and L. trichophora (Allgén, 1951) Matthes, 1956, on the nematode Spirina parasitifera, and L. tuba (Zelinka, 1914) Curds, 1987 on echinoderms (Curds, 1987). Finally, L. bosporica was found on Desmoscolex minutus in the Black Sea (Seergeva \& Dovgal, 2016). However, Thecacineta cothurnioides and Trematosoma rotunda are the only suctorians previously found as epibionts on a nematode species of the genus Tricoma from the Indian coasts of the Arabian Sea, where they share this basibiont together with another nematode, Pseudochromadora sp. (Dovgal et al. 2009). Some unidentified ciliates were also reported as epibionts with this genus from mangroves in the tropical NE coasts of Queensland, Autralian, together with some other nematodes, mainly from the family Desmodoridae (Fisher, 2003). Accordingly, our finding not only reported a new species of the suctorian Loricophrya, but also the first known association with a deep-sea species of Tricoma and the first record of the in the Mediterranean Sea for this suctorian genus.

The presence of protozoan ciliate epibionts on Tricoma may not affect negatively the basibiont (interference mediation). Desmodorid nematodes are often reported to produce mucus (Blome \& Riemann, 1987), this favouring the presence of attached particles and bacterial films on the cuticle so that the ciliates may be taking advantage of the host as a point of attachment in a microhabitat where microbial activity is high (Fenchel, 1987), likely feeding on either the own nematode mucus or on the bacterial film. This agrees with the position of the specimens of $L$. mediterranea sp. nov. in the final part of the basibiont body, the tail region near the anus or the cloaca, where the amount of secretions/excretions (i.e. a possible foo source) is expected to be more abundant (Fisher, 2003). As a result, diverse trophic links could be established within the epibiont community, in a similar way as it occurs in free-living species. It has been suggested that some epibionts may also feed on other members of the epibiotic community associated with the host (including other protozoa) that may move free on the basibiont and, for instance, suctorians may feed on other ciliates (Fernandez-Leborans \& von Rintelen, 2010). This implies that the epibionts receive an energy feedback (which may include the exploitation of the microbial loop, as well as other trophic 
relationships) as a result of their association with the basibiont and its associated epibiotic community, so that these tag-along riders may certainly obtain a benefit and more than simply hitch-hikers, they could be considered as real ectocommensals, as suggested by Fisher (2003).

On the other hand, suctorians may affect negatively the basibiont survivorship (exploitative mediation), particularly in case of a heavy colonization, by increasing the risk of predation on the host. Among other effects, they may modify the chemical signals acting on mobility, but also they may decrease the sensory activity and increase the energy costs, as well as cause substantial shift on interspecific interactions. In addition, they may also affect the basibiont biological functions, as they may compete for the available nutrients, delay or inhibit moulting, increase basibiont's weight and friction with water, impede transepidermal exchanges, etc. (Fernndez-Leborans 2010; Wahl et al. 2012). For instance, the copepod Acartia hudsonica Pinhey, 1926 had slower sinking rates when infested by the solitary peritrich, Rhabdostyla sp. Kent, 1881, suggesting that the epibiont increased the burden drag forces, thereby impeding locomotion and increasing the host energy expenses (Weissman et al. 1993). Indirectly, this lead the epibion/basibiont entity more susceptible to predation, eventually decreasing the fitness of the respective populations.

Nowadays it is not clear whether the interference or exploitative mediation predominates in suctorian/nematode relationships. However, similar relationships have repeatedly evolved (and not only with nematode hosts), suggesting that there have to be real benefits for the ciliates. The cost/benefit balance, however, appears to be uneven. The potential costs for the basibiont seems to be greater than the possible benefits, while the potential benefits for the epibionts seems to be greater than any costs (Key et al. 1999). Unfortunately, most species/associations are known from preserved materials and this is particularly true for the deep-sea ones like L. mediterranea $\mathrm{sp}$. nov. Therefore, no functional information can easily be inferred. Deep-sea associations appear also to be rare, either because they are not frequent or, more likely, because the overall lack of knowledge of these environments in the world oceans. Therefore, the quantification of the real presence of epibiotic ciliates on deep-sea nematode populations, as well as the evaluation of the functional impacts of the association in epibiont/basibiont partnerships still remain poorly known and further studies are certainly required to assess these interesting questions.

\section{ACKNOWLEDGEMENTS}

This paper is a contribution of SR and DM to the Research Projects CTM2010-21810-C03-03 and CTM2013-43287-P, funded by the Spanish National Scientific and Technical Research and Innovation Plan of the Ministry of Economy of Spain, and to the Consolidated Research Group on Marine Benthic Ecology of the Generalitat de Catalunya (2014SGR120).

\section{REFERENCES}

Álvarez-Campos, P., Fernández-Leborans, G., Verdes, A., San Martín, G., Martin, D., \& Riesgo, A. (2014) The tag-along friendship: epibiotic protozoans and syllid polychaetes. Implications for the taxonomy of Syllidae (Annelida), and description of three new species of Rhabdostyla and Cothurnia (Ciliophora, Peritrichia). Zoological Journal of the Linnean Society, 172(2), 265-281.

Amblas, D., Canals, M., Urgeles, R., Lastras, G., Liquete, C., Hughes-Clarke, J. E., Casamor, J. L. \& Calafat, A. M. (2006) Morphogenetic mesoscale analysis of the northeastern Iberian margin, NW Mediterranean Basin. Marine Geology, 234(1), 3-20.

Bhattacharjee, D. (2014) Suctorian epibionts on Chromaspirina sp. (Nematoda: Desmodoridae) from the shallow continental shelf of the Bay of Bengal, northern Indian Ocean. Marine Biodiversity Records, 7, 1. 
Blome, D. \& Riemann, F. (1987) A sediment agglutination on females of the free-living marine nematode Desmodora schulzi. Helgoländer Meeresuntersuchungen, 41, 113-119.

De Grisse AT (1969) Redescription ou modifications de quelques techniques utilisées dans l'étude des nematodes phytoparasitaires. Mededelingen Rijksfakulteit Landbouwwetenschappen, Gent, 34, 351-369.

Dovgal, I. V., Chatterjee, T., \& Baban, I. (2008) An overview of suctorian ciliates (Ciliophora, Suctorea) as epibionts of halacarid mites (Acari, Halacaridae). Zootaxa, (25 Jun), 60-68.

Dovgal I., Chatterjee T. \& Ingole B. (2009a) New records of Thecacineta cothurnioides and Trematosoma rotunda (Ciliophora, Suctorea) as epibionts on nematodes from the Indian Ocean. Protistology 6, 19-23.

Dovgal, I., Chatterjee, T., Rao, D. S., Chan, B. K., \& De Troch, M. (2009) New records of Praethecacineta halacari (Schulz)(Suctorea: Ciliophora) from Taiwan, Tanzania and Canada. Marine Biodiversity Records, 2, e136.

Dovgal, I. V., Chatterjee, T., Ingole, B., \& Nanajкar, M. (2008) First report of Limnoricus ponticus Dovgal \& Lozowskiy (Ciliophora: Suctorea) as epibionts on Pycnophyes (Kinorhyncha) from the Indian Ocean with key to species of the genus Limnoricus. Cah. Biol. Mar/, (49), 381-385.

Fenchel, T. (1987) Ecology of Protozoa. The biology of free-living phagotrophic protists. Madison, Wisconsin: Springer-Verlag, Berlin, p. 52. [Brock/Springer Series in Contemporary Bioscience. ScienceTechnical Publishers.]

Fernandez-Leborans, G. (2010) Epibiosis in Crustacea: an overview. Crustaceana, 83(5), 549.

Fernandez-Leborans, G., \& Von Rintelen, K. (2010) Biodiversity and distribution of epibiontic communities on Caridina ensifera (Crustacea, Decapoda, Atyidae) from Lake Poso: comparison with another ancient lake system of Sulawesi (Indonesia). Acta Zoologica, 91(2), 163-175.

Fisher R. (2003) Ciliate hitchhikers - nematode ecto-commensals from tropical Australian sea grass meadows. Journal of the Marine Biological Association of the United Kingdom 83, 445-446.

Gili, J.-M., Bouillon, J., Pagès, F., Palanques, A. \& Puig, P. (1999) Submarine canyons as habitat of singular plankton populations: three new deep-sea hydromedusae in the western Mediterranean. Zoological Journal of the Linnean Society, 125: 313-329.

Gili, J.-M., Bouillon, J., Pagès, F., Palanques, A.. Puig, P. \& Heussner, S. (1998) Origin and biogeography of deep water Mediterranean Hydromedusae including the description of two new species collected in submarine canyons of Northwestern Mediterranean. Scientia Marina, 62(1-2): 113-134.

Gili, J. M., Puig, P., Pagès, F., Palanques, A., Boullion, J., \& Heussner, S. (2000) Deep-water Hydromedusae from the Lacaze-Duthiers submarine canyon (Banyuls, north-western Mediterranean) and description of two new genera (Guillea and Parateclaia). Scientia Marina, 64(1), 87-95.

Ingole, B., Singh, R., Sautya, S., Dovgal, I., \& Chatterjee, T. (2009) Report of epibiont Thecacineta calix (Ciliophora: Suctorea) on deep-sea Desmodora (Nematoda) from the Andaman Sea, Indian Ocean. Marine Biodiversity Records, 3, e46

Key Jr, M. M., Winston, J. E., Volpe, J. W., Jeffries, W. B., \& Voris, H. K. (1999) Bryozoan fouling of the blue crab Callinectes sapidus at Beaufort, North Carolina. Bulletin of Marine Science, 64(3), 513-533.

Lastras, G., Canals, M., Amblas, D., Lavoie, C., Church, I., De Mol, B., Duran, R., Calafat, A. M., HuhesClarke, J. E., Smith, C. J. \& Heussner, S. (2011) Understanding sediment dynamics of two large submarine valleys from seafloor data: Blanes and La Fonera canyons, northwestern Mediterranean Sea. Marine Geology, 280(1), 20-39.

Muthumbi, A., Verschelde, D. \& Vincx, M. (1995) New Desmodoridae (Nematoda: Desmodoroidea): three new species from Ceriops mangrove sediments (Kenya) and one related new species from the North Sea. Cahiers de Biologie Marine, 36, 181-195.

Nicholas, W. L., Stewart, A. C. \& Marples, T. G. (1988) Field and laboratory studies of Desmodora cazca Gerlach, 1956 (Desmodoridae: Nematoda) from mangrove mud-fats. Nematologica, 34, 331-349.

Platt, H. M. \& Warwick, R. M. (1988) Free-living marine nematodes. Part II: British chromadorids. Brill/Backhuys, for the Linnean Society of London and the Estuarine and Brackish-Water Sciences Association.

Román, S., Vanreusel, A., Romano, C., Ingels, J., Puig, P., Company, J.B., Martin, D., submitted. High spatiotemporal variability in meiofauna assemblages in Blanes Canyon (NW Mediterranean) subject to anthropogenic and natural disturbances. Deep-Sea Res.I.

Romano, C., Coenjaerts, J., Fleixas, M.M., Zúñiga, D., Vanreusel, A., Company, J.B., Martin, D. (2013) Spatiotemporal variability of meiobenthic density in the Blanes submarine canyon (NW Mediterranean). Progress In Oceanography 118, 159-174.

Romano, C., Voight, J.R., Company, J.B., Plyuscheva, M., Martin, D. (2013b) Submarine canyons as preferred habitat for wood-boring species of Xylophaga (Mollusca, Bivalvia). Progress In Oceanography 118, 175187.

Sardà, F., Company, J.B., Bahamón, N., Rotllant, G., Flexas, M.M., Sánchez, J.D., Zúñiga, D., Coenjaerts, J., Orellana, D., Jordà, G., Puigdefábregas, J., Sánchez-Vidal, A., Calafat, A., Martín, D., Espino, M. (2009) 
Relationship between environment and the occurrence of the deep-water rose shrimp Aristeus antennatus (Risso, 1816) in the Blanes submarine canyon (NW Mediterranean). Progress In Oceanography 82, $227-$ 238.

Sardá, R., Gil, J., Taboada, S., Gili, J. M. (2009) Polychaete species captured in sediment traps moored in northwestern Mediterranean submarine canyons. Zoological dssddJournal of the Linnean Society 155, 1-21.

Sevastou, K., Corgosinho, P. H. C., Arbizu, P. M. (2012) A new species of Dahmsopottekina (Copepoda: Harpacticoida: Huntemanniidae) from the western Mediterranean deep sea. Journal of the Marine Biological Association of U.K. 92, 1043-1055.

Sergeeva, N., \& Dovgal, I. (2016) Loricophrya bosporica n. sp. (Ciliophora, Suctorea) epibiont of Desmoscolex minutus (Nematoda, Desmoscolecida) from oxic/anoxic boundary of the Black Sea Istanbul Strait's outlet area. Zootaxa, 4061(5), 596-600.

Tazioli, S., \& Di Camillo, C. G. (2013) Ecological and morphological characteristics of Ephelota gemmipara (Ciliophora, Suctoria), epibiontic on Eudendrium racemosum (Cnidaria, Hydrozoa) from the Adriatic Sea. European Journal of Protistology, 49(4), 590-599.

Tecchio, S., Ramírez-Llodra, E., Aguzzi, J., Sanchez-Vidal, A., Flexas, M. M., Sardà, F., \& Company, J. B. (2013) Seasonal fluctuations of deep megabenthos: Finding evidence of standing stock accumulation in a flux-rich continental slope. Progress in Oceanography, 118, 188-198

Wahl, M. (2008) Ecological lever and interface ecology: epibiosis modulates the interactions between host and environment. Biofouling, 24(6), 427-438.

Wahl, M., Goecke, F. R., Labes, A., Dobretsov, S., \& Weinberger, F. (2012) The second skin: ecological role of epibiotic biofilms on marine organisms. Frontiers in Microbiology, 3, 292.

Weissman, P., Lonsdale, D. J., \& Yen, J. (1993) The effect of peritrich ciliates on the production of Acartia hudsonica in Long Island Sound. Limnology and Oceanography, 38(3), 613-622. 


\section{Figure legends}

Figure 1. Loricophrya mediterranea sp. nov. Location of the two specimens (a and b) found at $1227 \mathrm{~m}$ depth on the surface of Tricoma sp.; scale bar: $20 \mu \mathrm{m}$.

Figure 2. Loricophrya mediterranea sp. nov. Location of the specimen found at $1450 \mathrm{~m}$ depth on the surface of Tricoma sp.; scale bar: $20 \mu \mathrm{m}$.

Figures 3. Loricophrya mediterranea sp. nov. detail of specimen a from $1227 \mathrm{~m}$ depth, showing the location of the macronucleus (white arrow) and the ciliate body (black arrow) with the tentacles ( $\mathrm{t}$ ) near the opening of the lorica (1); scale bar: $20 \mu \mathrm{m}$.

Figure 4. Loricophrya mediterranea sp. nov. detail of specimen b from $1227 \mathrm{~m}$ depth; scale bar: $20 \mu \mathrm{m}$.

Figure 5. Loricophrya mediterranea sp. nov. Close view of the capitate (clavate) tentacles; scale bar: $20 \mu \mathrm{m}$.

Figure 6. Loricophrya mediterranea sp. nov. Scheme of the ciliate body. 1, lorica; ma, macronucleus; t, tentacles; scale bar: $20 \mu \mathrm{m}$.
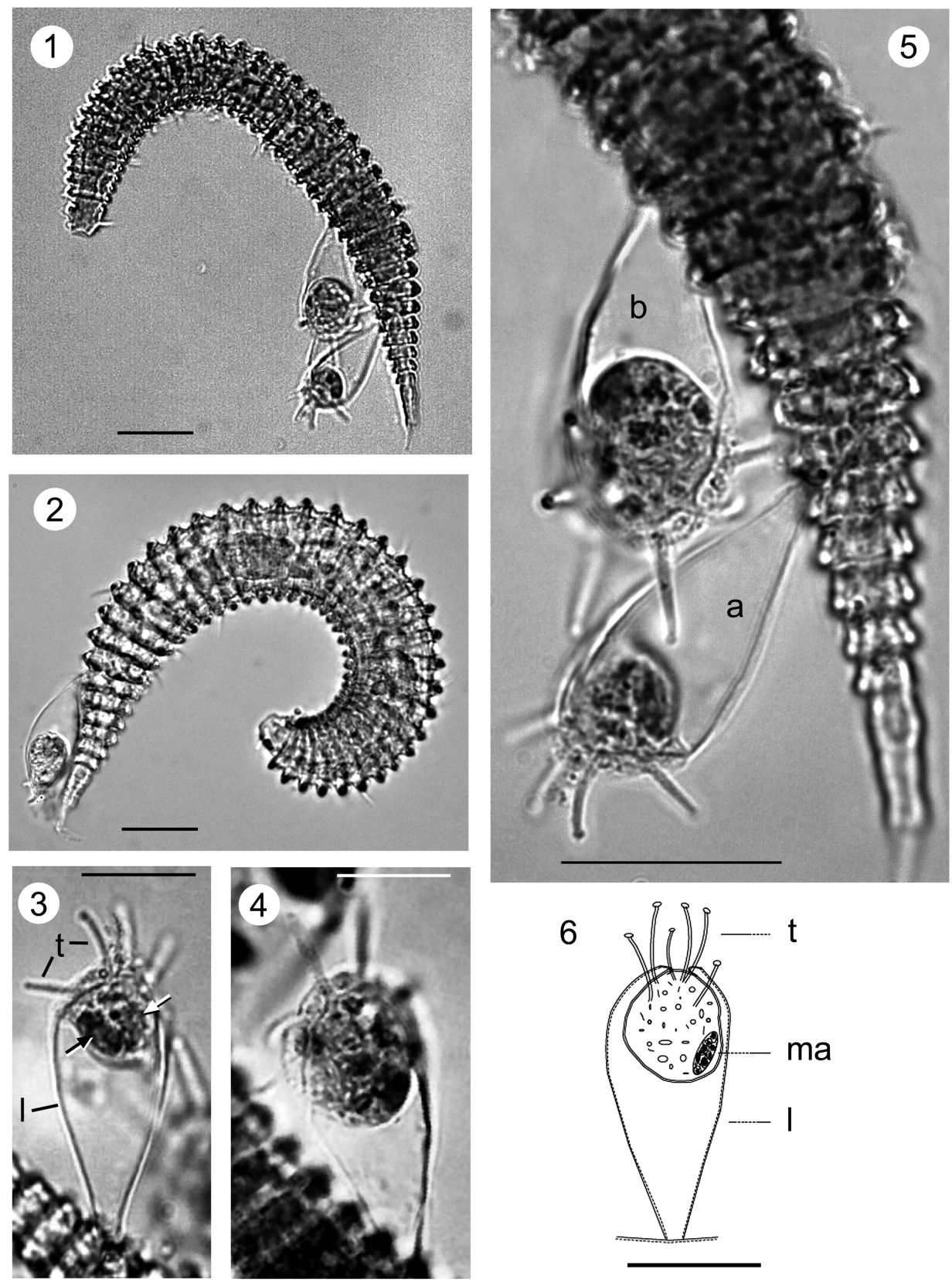